\title{
Interstitial positions of tin ions in alpha-(FerichSn)(2)0-3 solid solutions prepared by mechanical alloying
}

Jiang, Jianzhong; Lin, Rong; Nielsen, Kurt; Mørup, Steen; Rickerby, D.G.; Clasen, R.

Published in:

Physical Review B Condensed Matter

Link to article, DOI:

10.1103/PhysRevB.55.14830

Publication date:

1997

Document Version

Publisher's PDF, also known as Version of record

Link back to DTU Orbit

Citation (APA):

Jiang, J., Lin, R., Nielsen, K., Mørup, S., Rickerby, D. G., \& Clasen, R. (1997). Interstitial positions of tin ions in alpha-(FerichSn)(2)O-3 solid solutions prepared by mechanical alloying. Physical Review B Condensed Matter, 55(22), 14830-14835. https://doi.org/10.1103/PhysRevB.55.14830

\section{General rights}

Copyright and moral rights for the publications made accessible in the public portal are retained by the authors and/or other copyright owners and it is a condition of accessing publications that users recognise and abide by the legal requirements associated with these rights.

- Users may download and print one copy of any publication from the public portal for the purpose of private study or research.

- You may not further distribute the material or use it for any profit-making activity or commercial gain

- You may freely distribute the URL identifying the publication in the public portal 


\title{
Interstitial positions of tin ions in $\alpha-\left(\mathrm{Fe}_{\text {rich }} \mathrm{Sn}\right)_{2} \mathrm{O}_{3}$ solid solutions prepared by mechanical alloying
}

\author{
J. Z. Jiang ${ }^{*}$ and R. Lin \\ Department of Physics, Building 307, Technical University of Denmark, DK-2800 Lyngby, Denmark \\ K. Nielsen \\ Department of Chemistry, Building 207, Technical University of Denmark, DK-2800 Lyngby, Denmark \\ S. Mørup \\ Department of Physics, Building 307, Technical University of Denmark, DK-2800 Lyngby, Denmark \\ D. G. Rickerby \\ Institute for Advanced Materials, European Commission, Joint Research Centre, 21020 Ispra (VA), Italy \\ R. Clasen \\ INM Institut für Neue Materialien, D-66123 Saarbrücken, Germany
}

(Received 17 December 1996)

\begin{abstract}
The microstructure of samples of 94, 85, and $71 \mathrm{~mol} \% \alpha-\mathrm{Fe}_{2} \mathrm{O}_{3}-\mathrm{SnO}_{2}$, prepared by mechanical alloying, has been studied by $x$-ray diffraction with Rietveld structure refinements. On the basis of the structure refinements to the whole $\mathrm{x}$-ray diffraction patterns for the four as-milled samples, it is found that tin ions do not substitute iron ions in the solid solution, although this model is generally assumed in the literature. The $\mathrm{Sn}^{4+}$ ions occupy the empty octahedral holes in the lattice of the $\alpha-\mathrm{Fe}_{2} \mathrm{O}_{3}$ phase. [S0163-1829(97)00421-9]
\end{abstract}

\section{INTRODUCTION}

Mineral assemblages containing hematite $\left(\alpha-\mathrm{Fe}_{2} \mathrm{O}_{3}\right)$ and cassiterite $\left(\mathrm{SnO}_{2}\right)$ are of geological and economic importance. Recently, it has been found that $\alpha-\mathrm{Fe}_{2} \mathrm{O}_{3}-\mathrm{SnO}_{2}$ materials, prepared by a chemical method ${ }^{1}$ or mechanical alloying, ${ }^{2}$ exhibit a high gas sensitivity to $\mathrm{CH}_{4}$ and $\mathrm{C}_{2} \mathrm{H}_{5} \mathrm{OH}$ gases i.e., the conductivity is significantly altered. These are nanostructured $\alpha-\mathrm{Fe}_{2} \mathrm{O}_{3}-\mathrm{SnO}_{2}$ solid solutions, whereas the equilibrium mutual solid solubility is negligible at temperatures below $740 \mathrm{~K}^{3}$ The microstructure of the $\alpha-\mathrm{Fe}_{2} \mathrm{O}_{3} \mathrm{SnO}_{2}$ solid solutions has been studied by various techniques, such as $\mathrm{x}$-ray diffraction, ${ }^{1,2,4,5}$ extended $\mathrm{x}$-ray absorption fine structure ${ }^{6}$ (EXAFS), density measurement, ${ }^{4}$ optical microscopy, ${ }^{4}$ and ${ }^{57} \mathrm{Fe}$ and ${ }^{119} \mathrm{Sn}$ Mössbauer spectroscopy. ${ }^{1,2,5,7}$ From the variation of the density, ${ }^{4}$ the Mössbauer resonant line broadening, ${ }^{1,2,7}$ and the lower $\mathrm{Fe}-\mathrm{Fe}, \mathrm{Sn}-\mathrm{Fe}$, and $\mathrm{Fe}-\mathrm{O}$ coordination numbers ${ }^{6}$ in the $\left(\alpha-\mathrm{Fe}_{2} \mathrm{O}_{3}\right)_{\text {rich }}-\left(\mathrm{SnO}_{2}\right)$ solid solutions, it was suggested that anionic and cationic vacancies occur in the $\alpha-\mathrm{Fe}_{2} \mathrm{O}_{3}$ lattice. In general, it has been assumed that tin ions substitute iron ions in the lattice when tin ions dissolve in $\alpha-\mathrm{Fe}_{2} \mathrm{O}_{3}$ due to the similar ionic sizes of $\mathrm{Fe}^{3+}$ and $\mathrm{Sn}^{4+} \cdot{ }^{1,2,4-11}$ To the best of our knowledge, no experimental evidence has been reported to examine whether or not the substitution model is valid in this system. In x-ray diffraction studies ${ }^{1,2}$ of $\alpha-\mathrm{Fe}_{2} \mathrm{O}_{3}-\mathrm{SnO}_{2}$ solid solutions prepared by the chemical method or mechanical alloying, some diffraction peak intensities are observed to be dependent on the tin content, and this has not yet been completely understood. The origin of these aspects is the subject of this paper, which will also be of relevance for the $\alpha-\mathrm{Fe}_{2} \mathrm{O}_{3}-M \mathrm{O}_{2} \quad(M=$ metal element $)$ systems. Four $\alpha-\mathrm{Fe}_{\text {rich }} \mathrm{Sn}_{2} \mathrm{O}_{3}$ solid solutions prepared by mechanical alloying have been investigated by x-ray diffraction with Rietveld structure refinements. On the basis of structure refinements of these samples, it was found that the substitution model seems to be unable to describe the experimental data. Using a model in which an interstitial position for the dissolved tin ions in $\alpha-\mathrm{Fe}_{2} \mathrm{O}_{3}$ is proposed, the whole $\mathrm{x}$-ray diffraction patterns for the four samples can be well fitted. It is found that anionic and cationic vacancies are formed. This verifies the suggestion made in earlier studies. ${ }^{1,2,4,6}$

\section{EXPERIMENT}

Samples of $\alpha-\mathrm{Fe}_{2} \mathrm{O}_{3}-\mathrm{SnO}_{2}$ were prepared by mixing powders of hematite $\left(\alpha-\mathrm{Fe}_{2} \mathrm{O}_{3}\right)(99.9 \%$ purity, particle size $\approx 10$ $\mu \mathrm{m}$ and cassiterite $\left(\mathrm{SnO}_{2}\right)(99.9 \%$ purity, particle size $\approx 10$ $\mu \mathrm{m})$ with three nominal compositions of 94,85 , and 71 mol $\% \alpha-\mathrm{Fe}_{2} \mathrm{O}_{3}$. The milling was carried out in an open container (i.e., the valves on the lid were open during milling) using a planetary ball mill (Fritsch Pulverisette 5), with tungsten carbide (WC) vials and balls. ${ }^{12}$ Thus air was constantly available to the oxide powders during milling. The milling intensity was 200 rotations per minute, and a ball-topowder weight ratio of 20:1 was chosen. The milling time for the first three samples of 94, 85, and $71 \mathrm{~mol} \%$ $\alpha-\mathrm{Fe}_{2} \mathrm{O}_{3}$ was $110 \mathrm{~h}$ (marked $a$ hereafter), and the fourth sample with $71 \mathrm{~mol} \% \quad \alpha-\mathrm{Fe}_{2} \mathrm{O}_{3}$ was milled for $151 \mathrm{~h}$ (marked $b$ hereafter). The compositions of the samples were examined by scanning electron microscopy with an energydispersive $\mathrm{X}$-ray analysis facility. It was found that the tungsten contamination originating from the abrasion of the vials 


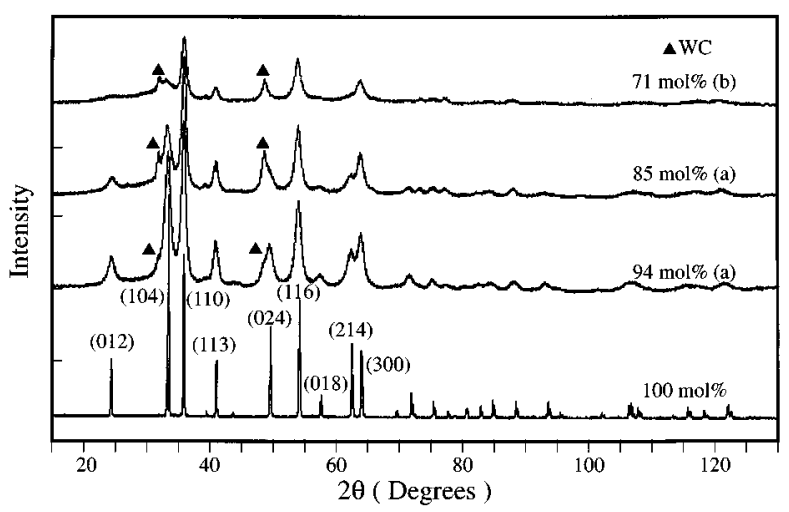

FIG. 1. X-ray powder diffraction patterns for the three as-milled 94, 85, and $71 \mathrm{~mol} \% \alpha-\mathrm{Fe}_{2} \mathrm{O}_{3}-\mathrm{SnO}_{2}$ samples with milling times of $110 \mathrm{~h}(\mathrm{a})$ and $151 \mathrm{~h}(\mathrm{~b})$, together with pure unprocessed $\alpha-\mathrm{Fe}_{2} \mathrm{O}_{3}$.

and balls was less than 2 and 3 at. \% for the samples milled for 110 and $151 \mathrm{~h}$, respectively. The samples have been characterized by several experimental techniques: x-ray diffraction, transmission electron microscopy (TEM) and ${ }^{57} \mathrm{Fe}$ and ${ }^{119} \mathrm{Sn}$ Mössbauer spectroscopy. Preliminary results on the alloying process for the $94 \mathrm{~mol} \% \alpha-\mathrm{Fe}_{2} \mathrm{O}_{3}-\mathrm{SnO}_{2}$ samples have been published. ${ }^{7}$ The $\mathrm{x}$-ray diffraction data were collected in Bragg-Brentano scattering geometry with a Philips PW1820/3711 diffractometer using $\mathrm{Cu}$ $K \alpha$ radiation. The data were collected in the $2 \theta$ range of $15^{\circ}-130^{\circ}$ with a step length of $0.02^{\circ}$ and a counting time of $35 \mathrm{~s}$ per step. A graphite monochromator and an automatic divergence slit were used. Normally, using a diffractometer, the surface area exposed to the radiation at small angles is larger than that at large angles. This leads to a systematic error. However, by the application of an automatic divergence slit, the surface area exposed to the radiation is maintained constant during the whole scan and so the systematic error can be limited. The Rietveld refinement program ${ }^{13} \mathrm{em}-$ ployed pseudo-Voigt functions limited to nine half widths, asymmetry corrections, a Lorentzian component $\gamma=\gamma_{1}$ $+\gamma_{2}(2 \theta)$ and full width at half maximum (FWHM) defined as $\left(U \tan ^{2} \theta+V \tan \theta+W\right)^{1 / 2}$. Here $\gamma_{1}, \gamma_{2}, U, V$, and $W$ are fitting parameters. Due to the small grain size in the milled samples, the Bragg peak widths were broadened. Furthermore, the structure in grain boundaries was assumed as an amorphous like structure, which was modeled as a background by 15 parameters (Chebyshev type I). ${ }^{14}$

\section{RESULTS AND DISCUSSION}

Figure 1 shows the $\mathrm{x}$-ray diffraction patterns of the milled 94, 85, and $71 \mathrm{~mol} \% \alpha-\mathrm{Fe}_{2} \mathrm{O}_{3}-\mathrm{SnO}_{2}$ samples together with that of pure unprocessed $\alpha-\mathrm{Fe}_{2} \mathrm{O}_{3}$. The average grain sizes for the samples prepared by mechanical alloying obtained from TEM observations are $\sim 10 \mathrm{~nm}$, which are in agreement with that previously determined using the Scherrer method. ${ }^{7}$ Due to the small grain size for the milled samples, all diffraction peaks are broadened compared to those for pure unprocessed $\alpha-\mathrm{Fe}_{2} \mathrm{O}_{3}$. By comparing the patterns for the milled $\alpha-\mathrm{Fe}_{2} \mathrm{O}_{3}-\mathrm{SnO}_{2}$ samples with that for pure unprocessed $\alpha-\mathrm{Fe}_{2} \mathrm{O}_{3}$, it is found that the positions of the diffraction peaks for the milled samples (except the peaks for the tungsten carbide phase) are almost the same as the corresponding

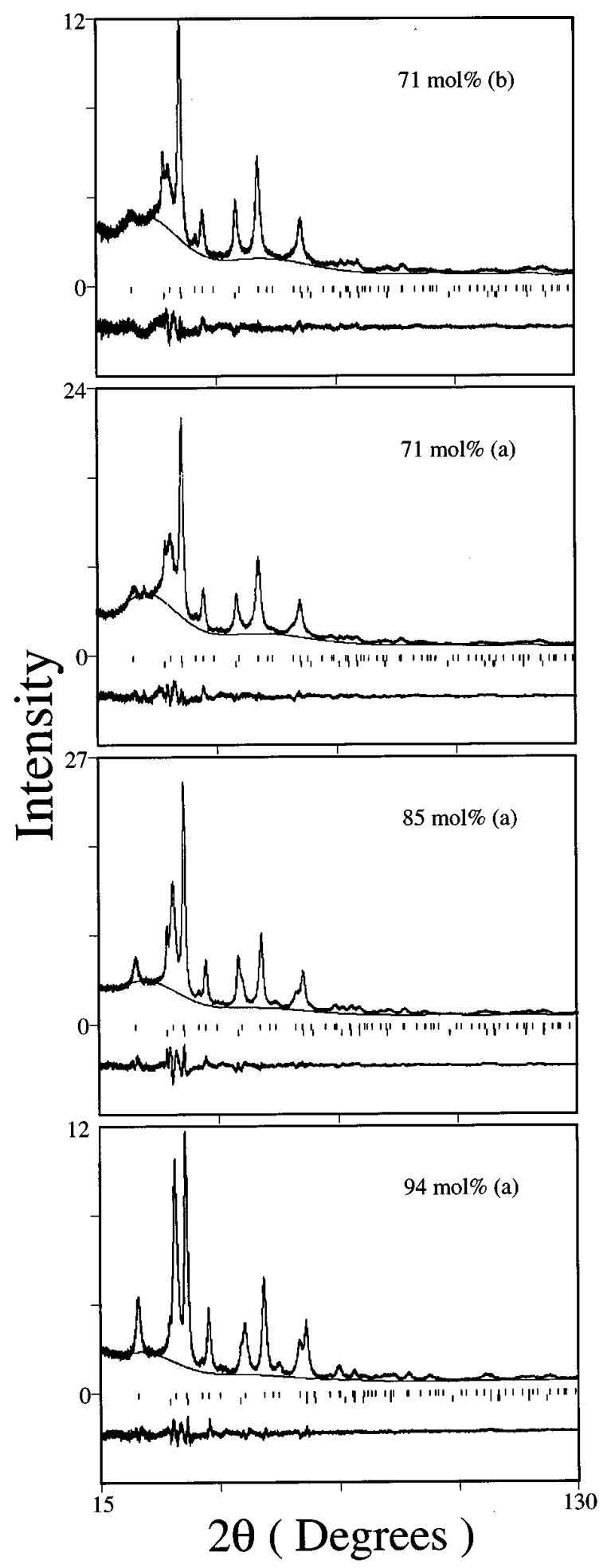

FIG. 2. Rietveld structure refinement profiles of the x-ray diffraction data for the four as-milled 94, 85, and $71 \mathrm{~mol} \%$ $\alpha-\mathrm{Fe}_{2} \mathrm{O}_{3}-\mathrm{SnO}_{2}$ samples prepared by mechanical alloying with milling times of $110 \mathrm{~h}$ (a) and $151 \mathrm{~h} \mathrm{(b).} \mathrm{The} \mathrm{description} \mathrm{of} \mathrm{the} \mathrm{plots} \mathrm{is}$ given in the text.

peaks for pure unprocessed $\alpha-\mathrm{Fe}_{2} \mathrm{O}_{3}$. This implies that the basic structure of the milled samples is still a phase with a structure similar to hematite. However, in all milled samples the diffraction (110) peak is the strongest peak, instead of the (104) peak, which is the strongest one for pure unprocessed 
TABLE I. Reliability $R$ factors of the Rietveld structure refinements for the four as-milled 94, 85, and $71 \mathrm{~mol} \% \alpha-\mathrm{Fe}_{2} \mathrm{O}_{3}-\mathrm{SnO}_{2}$ samples prepared by mechanical alloying with milling times of 110 $\mathrm{h}(\mathrm{a})$ and $151 \mathrm{~h} \mathrm{(b)}$

\begin{tabular}{ccccc}
\hline \hline $\begin{array}{c}\alpha-\mathrm{Fe}_{2} \mathrm{O}_{3} \\
(\mathrm{~mol} \%)\end{array}$ & $\begin{array}{c}R_{P} \\
(\%)^{\mathrm{a}}\end{array}$ & $\begin{array}{c}R_{\mathrm{WP}} \\
(\%)^{\mathrm{b}}\end{array}$ & $\begin{array}{c}R_{B} \\
(\text { hematite })(\%)^{\mathrm{c}}\end{array}$ & $\mathrm{GOF}^{\mathrm{d}}$ \\
\hline $94(\mathrm{a})$ & 4.96 & 6.32 & 1.33 & 2.0 \\
$85(\mathrm{a})$ & 5.79 & 6.99 & 1.71 & 3.7 \\
$71(\mathrm{a})$ & 3.79 & 4.93 & 0.83 & 2.0 \\
$71(\mathrm{~b})$ & 4.22 & 5.52 & 0.85 & 1.5 \\
\hline \hline
\end{tabular}

${ }^{\mathrm{a}} R_{P}=\Sigma\left|y_{\mathrm{obs}, i}-y_{\text {calc }, i}\right| / \Sigma y_{\mathrm{obs}, i}$, where $y_{\mathrm{obs}, i}$ and $y_{\text {calc }, i}$ represent the observed and calculated intensities at the $i$ th step, respectively (Ref. 14).

${ }^{\mathrm{b}} R_{\mathrm{WP}}=\left[\Sigma w_{i}\left(y_{\mathrm{obs}, i}-y_{\mathrm{calc}, i}\right)^{2} / \Sigma w_{i}\left(y_{\mathrm{obs}, i}\right)^{2}\right]^{1 / 2}$ and $w_{i}=1 / y_{\mathrm{obs}, i}$ is a weight scheme (Ref. 14).

${ }^{c}$ Bragg peak intensity $R$-factor $R_{B}=\Sigma \mid I_{\mathrm{obs}, i}-I_{\mathrm{calc}, i} / \Sigma I_{\mathrm{obs}, i}$ (Ref. $14)$.

d، "Goodness of fit" $\mathrm{GOF}=R_{\mathrm{WP}} / R_{\text {expected }}, \quad R_{\text {expected }}=[(N-P) /$ $\left.\sum w_{i}\left(y_{\mathrm{obs}, i}\right)^{2}\right]^{1 / 2}$, where $N$ is the number of observation data and $P$ is the number of fitting parameters (Ref. 14).

$\alpha-\mathrm{Fe}_{2} \mathrm{O}_{3}$. With increasing tin content in the samples, it is found that intensities of those diffraction peaks with Miller indices $(h k l)$ of $l \neq 3 n, n=0,1,2, \ldots$, are significantly reduced as compared to pure unprocessed $\alpha-\mathrm{Fe}_{2} \mathrm{O}_{3}$. A similar result was also reported by Takano et al. in chemically synthesized nanostructured $\alpha-\mathrm{Fe}_{2} \mathrm{O}_{3}-\mathrm{SnO}_{2}$ samples, but no clear explanation to the effect was reported. ${ }^{1}$

In order to clarify the effect, Rietveld structure refinements have been performed for the four milled samples as shown in Fig. 2. The reliability $R$ factors for all Rietveld refinements are listed in Table I. The lattice parameters, ion positions, and ion occupation factors for the milled samples obtained from the Rietveld refinements are listed in Table II and together with the reference data for the pure hematite phase. ${ }^{15}$ Before the interstitial model used for the Rietveld structure refinements is introduced, let us consider the structure of pure $\alpha-\mathrm{Fe}_{2} \mathrm{O}_{3}$. Hematite, $\alpha-\mathrm{Fe}_{2} \mathrm{O}_{3}$, has a corundum structure with a space group of $R \overline{3} C$ (No. 167), and one unit cell contains six formula units or "molecules" of $\mathrm{Fe}_{2} \mathrm{O}_{3}$. The hexagonal and rhombohedral structures of hematite are shown in Fig. 3. Its crystal structure is based on the oxygen hexagonal-close-packed lattice. The $\mathrm{Fe}^{3+}$ ions with coordi-

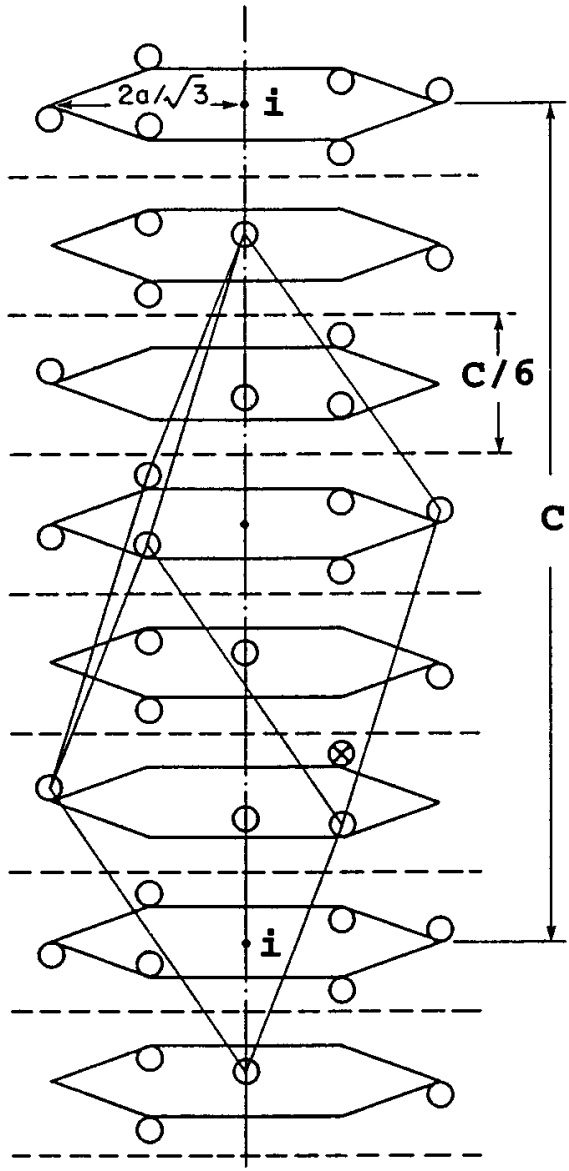

FIG. 3. Atomic arrangements in hematite (Ref. 16). The circles represent $\mathrm{Fe}^{3+}$ positions in the hexagonal structure. Note that some iron ions lie above and others below the hexagonal basal planes. The dashed lines indicate the planes in which the $\mathrm{O}^{2-}$ ions lie. The outward faces of the rhombohedral cell are also drawn; the circle marked $\times$ represents a corner ion for the inward faces. The origin position is marked with the character $i$.

nates of $(0,0, z)$, etc., occupy two-thirds of the octahedral holes in successive oxygen layers, and one-third of the octahedral holes with coordinates of $(0,0,0)$, etc., are empty. As mentioned before, it has generally been assumed that tin ions substitute iron ions in the $\alpha-\mathrm{Fe}_{2} \mathrm{O}_{3}$ lattice due to the similar ionic sizes of $\mathrm{Fe}^{3+}$ and $\mathrm{Sn}^{4+}$. From the ${ }^{57} \mathrm{Fe}$ and ${ }^{119} \mathrm{Sn}$ Mössbauer measurements of the four samples, ${ }^{7,17}$ it

TABLE II. Lattice parameters, ion positions, and occupation factors of the hematite like phase obtained by the Rietveld refinement of x-ray powder diffraction patterns for 94, 85, and $71 \mathrm{~mol}_{\%} \mathrm{Fe}_{2} \mathrm{O}_{3}-\mathrm{SnO}_{2}$ samples with milling times of $110 \mathrm{~h}(\mathrm{a})$ and $151 \mathrm{~h}(\mathrm{~b})$, together with the reference data for pure unprocessed $\alpha-\mathrm{Fe}_{2} \mathrm{O}_{3}$ (Ref. 15).

\begin{tabular}{ccccccc}
\hline \hline \multirow{2}{\alpha}{$\begin{array}{c}\alpha-\mathrm{Fe}_{2} \mathrm{O}_{3} \\
(\mathrm{~mol} \mathrm{\%})\end{array}$} & \multicolumn{2}{c}{ Cell parameters } & \multicolumn{2}{c}{ Ion positions $^{\mathrm{a}}$} & \multicolumn{2}{c}{ Occupation factor } \\
& $a(\AA)$ & $c(\AA)$ & $\mathrm{Fe}(z)$ & $\mathrm{O}(x)$ & $g_{\mathrm{Fe}}$ & $g_{\mathrm{Sn}}$ \\
\hline 100 & 5.038 & 13.772 & 0.3553 & 0.3027 & $1 / 3$ & 0 \\
94 & $5.046(2)$ & $13.817(1)$ & $0.3527(1)$ & $0.3258(6)$ & $0.325(4)$ & $0.004(2)$ \\
85 & $5.058(2)$ & $13.851(2)$ & $0.3504(3)$ & $0.3411(9)$ & $0.308(10)$ & $0.013(5)$ \\
71 & $5.073(4)$ & $13.886(4)$ & $0.3472(3)$ & $0.3333(2)$ & $0.277(10)$ & $0.028(5)$ \\
71 & $5.073(5)$ & $13.892(5)$ & $0.3463(3)$ & $0.3295(9)$ & $0.264(14)$ & $0.035(7)$ \\
\hline
\end{tabular}

The iron and oxygen ions have coordinates $(0,0, z)$ and $\left(x, 0, \frac{1}{4}\right)$, respectively. 
TABLE III. Calculated values of $\left|F_{H}\right|^{2}$ for six diffraction peaks with relatively high intensities in the three cases: pure $\alpha-\mathrm{Fe}_{2} \mathrm{O}_{3}$, the substitution model, and the interstitial model, together with the scattering factors and occupation factors of $\mathrm{Fe}^{3+}, \mathrm{Sn}^{4+}$, and $\mathrm{O}^{2-}$ ions.

\begin{tabular}{|c|c|c|c|c|c|c|}
\hline$k h l$ & $f_{\mathrm{Fe}}{ }^{\mathrm{a}}$ & $f_{\mathrm{O}}{ }^{\mathrm{a}}$ & $f_{\mathrm{Sn}}^{\mathrm{a}}$ & $\begin{array}{c}\text { Pure } \alpha-\mathrm{Fe}_{2} \mathrm{O}_{3} \\
g_{\mathrm{Fe}}=1 / 3 \\
g_{\mathrm{O}}=1 / 2\end{array}$ & $\begin{array}{c}\left|F_{H}\right|^{2} \text { (a.u.) } \\
\text { Substitution } \\
g_{\mathrm{Fe}}=0.296, \\
g_{\mathrm{Sn}}=0.028, \\
g_{\mathrm{O}}=1 / 2\end{array}$ & $\begin{aligned} \text { Interstitial } \\
g_{\mathrm{Fe}}=0.278, \\
g_{\mathrm{Sn}}=0.028, \\
g_{\mathrm{O}}=0.472\end{aligned}$ \\
\hline 012 & 21.326 & 6.685 & 43.098 & 5666 & 6223 & 672 \\
\hline 104 & 20.093 & 6.038 & 40.953 & 40314 & 45494 & 18383 \\
\hline 110 & 19.705 & 5.623 & 40.276 & 35145 & 40615 & 41883 \\
\hline 113 & 18.923 & 5.176 & 38.913 & 6144 & 6144 & 5403 \\
\hline 024 & 17.573 & 4.375 & 36.558 & 34598 & 39045 & 16609 \\
\hline 116 & 16.848 & 4.144 & 35.292 & 29897 & 32988 & 36381 \\
\hline
\end{tabular}

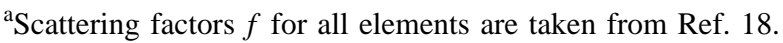

was found that no $\mathrm{Fe}^{2+}$ and $\mathrm{Sn}^{2+}$ ions or metallic tin atoms were present in the milled samples. Hence, in the substitution model, 4/3 $\mathrm{Fe}^{3+}$ ions must be removed per $\mathrm{Sn}^{4+}$ ion in $\alpha-\mathrm{Fe}_{2} \mathrm{O}_{3}$ due to charge balance. The first structural model to be refined was the substitution model. This completely failed by leading to negative occupation factors for $\mathrm{Sn}^{4+}$ (for example, $g_{\mathrm{Fe}}=0.393$ and $g_{\mathrm{Sn}}=-0.060$ for the $71 \mathrm{~mol} \%$ $\alpha-\mathrm{Fe}_{2} \mathrm{O}_{3}-\mathrm{SnO}_{2}$ sample with a milling time of $151 \mathrm{~h}$ ). But the difference electron density (observed minus calculated densities) showed an electron density of around $(0,0,0)$, the interstitial position (marked $i$ in Fig. 3) along the $c$ axis in the hematite structure. Therefore, an interstitial model has been developed to refine the x-ray diffraction patterns for the four samples. In this model, tin ions occupy the empty octahedral holes with coordinates of $(0,0,0)$, etc. The distance between the $\mathrm{Sn}^{4+}$ ion position and the two $\mathrm{Fe}^{3+}$ nearest neighbors is only $\sim 2 \AA$. From a physical point of view, it seems impossible that these two cations are so close to each other since the shortest $\mathrm{Fe}-\mathrm{Fe}$ distance is found to be larger than $2.6 \AA$ in pure $\alpha-\mathrm{Fe}_{2} \mathrm{O}_{3}$ phase and in the $\alpha-\mathrm{Fe}_{2} \mathrm{O}_{3}-\mathrm{SnO}_{2}$ solid solutions, listed in Tables IV and V. Consequently, the two $\mathrm{Fe}^{3+}$ ions must be removed per $\mathrm{Sn}^{4+}$ ion introduced in the structure. Furthermore, to maintain charge balance one $\mathrm{O}^{2-}$ ion must be removed per $\mathrm{Sn}^{4+}$ ion. This interstitial model has been used in all refinements, by which refinements converged to small $R$ values listed in Table I. Attempts to lower the symmetry did not result in any significant improvement of the refinements. In the upper field of each plot in Fig. 2, the experimentally observed pattern is shown. Below that the background is also plotted as a solid line in this field. The difference pattern (observed minus calculated patterns) is plotted in the lower field. In the intermediate field the positions of the possible Bragg reflections are indicated as a series of short vertical bars at different levels corresponding to the different crystalline phases $\left(\alpha-\mathrm{Fe}_{2} \mathrm{O}_{3}\right.$ and WC) in the sample. It is found that three phases are present. They are a predominant hematite like phase, a tungsten carbide phase originating from the abrasion of balls and vial, and a broadened background with a major peak at the vicinity of $2 \theta$ $=28^{\circ}$, which may be attributed to an amorphous like phase. ${ }^{57} \mathrm{Fe}$ and ${ }^{119} \mathrm{Sn}$ Mössbauer spectroscopy measurements on the four samples also showed that $\alpha-\mathrm{Fe}_{2} \mathrm{O}_{3}-\mathrm{SnO}_{2}$ solid solutions are formed during milling. ${ }^{7,17}$ The contents of $\mathrm{SnO}_{2}$ in the solid solutions are found to be about $2.4 \pm 2,7.8 \pm 3$, $16.8 \pm 3$, and $21.0 \pm 4 \mathrm{~mol} \%$ for the 94,85 , and $71 \mathrm{~mol} \%$ $\alpha-\mathrm{Fe}_{2} \mathrm{O}_{3}-\mathrm{SnO}_{2}$ and the $71 \mathrm{~mol} \%$ (b) samples, respectively. The dissolution of $\mathrm{Sn}^{4+}$ ions in $\alpha-\mathrm{Fe}_{2} \mathrm{O}_{3}$ results in changes in the lattice parameters of the corundum structure. Both the $a$ and $c$ axes of the hexagonal cell are elongated. The $a$ axis of the hexagonal cell increases with increasing $\mathrm{SnO}_{2}$ content at a rate of $0.17 \%$ per $\mathrm{SnO}_{2} \mathrm{~mol} \%$, while the $c$ axis increases at a rate of $0.05 \%$ per $\mathrm{SnO}_{2} \mathrm{~mol} \%$. These values are larger than the data reported in Ref. 1. One possible reason is that the values of the $\mathrm{SnO}_{2}$ concentration incorporated with $\alpha-\mathrm{Fe}_{2} \mathrm{O}_{3}$ used in Ref. 1 may be too large because not all $\mathrm{SnO}_{2}$ in the samples is incorporated in $\alpha-\mathrm{Fe}_{2} \mathrm{O}_{3}$. The positions of $\mathrm{Fe}^{3+}$ ions along the $z$ axis and $\mathrm{O}^{2-}$ ions along the $x$ axis have also been changed by adding $\mathrm{Sn}^{4+}$ to $\alpha-\mathrm{Fe}_{2} \mathrm{O}_{3}$, which could be due to the formation of anionic and cationic vacancies.

To illustrate the peak-intensity dependence on tin content, the values of the square of the absolute value of the structure factor, $\left|F_{H}\right|^{2}$, for six peaks with relatively higher intensities in three cases of pure $\alpha-\mathrm{Fe}_{2} \mathrm{O}_{3}$, the substitution model, and the interstitial model are calculated and listed in Table III together with the scattering factors and the occupation factors for $\mathrm{Fe}^{3+}, \mathrm{O}^{2-}$, and $\mathrm{Sn}^{4+}$ ions, respectively. The integrated intensity of the powder diffraction peaks $I_{H}$, where $H$ stands for the Miller indices $(h k l)$, is proportional to the square of the absolute value of the structure factor, $\left|F_{H}\right|^{2}$, which is given by,

$$
\begin{aligned}
F_{H}= & \sum_{j} f_{j} g_{j} \exp \left[-2 \pi i\left(h x_{j}+k y_{j}+1 z_{j}\right)\right] \\
& \times \exp \left(-\frac{B_{j} \sin ^{2} \theta}{\lambda^{2}}\right),
\end{aligned}
$$

where $f_{j}$ is the scattering factor for ion $j, g_{j}$ is the occupation factor of ion $j, x_{i}, y_{i}$, and $z_{i}$ are the fractional coordinates of the $j$ th ion, and $B_{j}$ is the temperature factor coefficient. The term $\exp \left(-B_{j} \sin ^{2} \theta / \lambda^{2}\right)$ results from thermal vibration of ions. For simplicity the thermal vibration effect in the calculation is neglected and only one tin ion in the unit cell is assumed. The qualitative features will still remain when more tin ions are incorporated in the unit cell and the 
TABLE IV. Fe-Fe distances $(d)$ and the corresponding average coordination numbers $(\mathrm{CN})$ in the hematite like phase for the 94, 85, and $71 \mathrm{~mol} \% \alpha-\mathrm{Fe}_{2} \mathrm{O}_{3}-\mathrm{SnO}_{2}$ samples with milling times of $110 \mathrm{~h}$ (a) and 151 h (b), together with the reference data of pure unprocessed $\alpha-\mathrm{Fe}_{2} \mathrm{O}_{3}$.

\begin{tabular}{cllllllll}
\hline \hline \multirow{2}{\alpha}{$\begin{array}{c}\alpha-\mathrm{Fe}_{2} \mathrm{O}_{3} \\
(\mathrm{~mol} \mathrm{\%})\end{array}$} & \multicolumn{2}{c}{$\mathrm{Fe}-\mathrm{Fe}(\mathrm{I})$} & \multicolumn{2}{c}{$\mathrm{Fe}-\mathrm{Fe}(\mathrm{II})$} & \multicolumn{2}{c}{$\mathrm{Fe}-\mathrm{Fe}(\mathrm{III})$} & \multicolumn{2}{c}{$\mathrm{Fe}-\mathrm{Fe}(\mathrm{IV})$} \\
& $\mathrm{CN}^{\mathrm{a}}$ & $d(\AA)$ & $\mathrm{CN}$ & $d(\AA)$ & $\mathrm{CN}$ & $d(\AA)$ & $\mathrm{CN}$ \\
\hline 100 & 2.900 & 1.00 & 2.971 & 3.00 & 3.364 & 3.00 & 3.705 & 6.00 \\
94 & 2.838 & 0.98 & 2.962 & 2.94 & 3.408 & 2.94 & 3.714 & 5.88 \\
85 & 2.781 & 0.92 & 2.958 & 2.76 & 3.449 & 2.76 & 3.722 & 5.52 \\
71 & 2.699 & 0.83 & 2.954 & 2.49 & 3.507 & 2.49 & 3.733 & 4.98 \\
71 & 2.673 & 0.79 & 2.951 & 2.28 & 3.521 & 2.28 & 3.734 & 4.74 \\
\hline \hline
\end{tabular}

${ }^{\mathrm{a}} \mathrm{CN}$ is defined as $\mathrm{CN}=\mathrm{CN}_{\text {pure }}\left(g_{\mathrm{Fe}} / g_{\mathrm{Fe}}^{\text {pure }}\right)$ and $g_{\mathrm{Fe}}^{\text {pure }}=1 / 3$.

thermal vibration effect is taken into account. In the substitution model, $4 / 3 \mathrm{Fe}^{3+}$ ions will be removed due to charge balance. In the interstitial model, as mentioned above, two $\mathrm{Fe}^{3+}$ ions and one $\mathrm{O}^{2-}$ ion will be removed. By comparing the theoretically calculated values of $\left|F_{H}\right|^{2}$ for the substitution model with those of pure $\alpha-\mathrm{Fe}_{2} \mathrm{O}_{3}$ (Table III), it is clearly seen that the values of $\left|F_{H}\right|^{2}$ increase for the substitution model, except for the (113) peak, which is only contributed by the oxygen ions in the lattice. This theoretical prediction is contrary to the experimental x-ray diffraction patterns. On the other hand, for the interstitial model, the intensities of peaks with Miller indices $(h k l)$ of $I \neq 3 n, n$ $=0,1,2, \ldots$, are dramatically reduced. These results are exactly reflected in the experimental $\mathrm{x}$-ray diffraction patterns observed for the milled samples. Therefore, it can be concluded that the tin substitution model is not suitable to explain the tin ion positions in the $\alpha-\mathrm{Fe}_{2} \mathrm{O}_{3}-\mathrm{SnO}_{2}$ solid solutions. Based on the refinements, we believe that tin ions occupy the empty octahedral holes when they enter into $\alpha-\mathrm{Fe}_{2} \mathrm{O}_{3}$ and that anionic and cationic vacancies are formed.

Due to the dissolution of $\mathrm{Sn}^{4+}$ ions in $\alpha-\mathrm{Fe}_{2} \mathrm{O}_{3}$, the local structures around $\mathrm{Fe}^{3+}$ ions have been altered. Tables IV and $\mathrm{V}$ show the $\mathrm{Fe}-\mathrm{Fe}, \mathrm{Sn}-\mathrm{Fe}$, and $\mathrm{Fe}-\mathrm{O}$ distances and the corresponding average coordination numbers for the four $\alpha$ - $\mathrm{Fe}_{2} \mathrm{O}_{3}-\mathrm{SnO}_{2}$ samples and together with the pure unprocessed $\alpha-\mathrm{Fe}_{2} \mathrm{O}_{3}$. Adding $\mathrm{Sn}^{4+}$ ions to $\alpha-\mathrm{Fe}_{2} \mathrm{O}_{3}$ changes the distances and coordination numbers of $\mathrm{Fe}-\mathrm{Fe}, \mathrm{Sn}-\mathrm{Fe}$, and $\mathrm{Fe}-\mathrm{O}$ bonds. The first two $\mathrm{Fe}-\mathrm{Fe}$ nearest distances decrease with increasing the $\mathrm{SnO}_{2}$ content, while the next two increase. On the other hand, the $\mathrm{Sn}-\mathrm{Fe}$ nearest-neighbor distance increases with the $\mathrm{SnO}_{2}$ content in the samples, while the next-nearest-neighbor distance decreases. When more tin ions occupy the empty octahedral holes, more iron ions will be removed from their sites, and hence the average coordination numbers will decrease with increasing $\mathrm{SnO}_{2}$ content. However, the changes in $\mathrm{Fe}-\mathrm{O}$ distances are not monotonic for all samples. In the samples with 94 and $85 \mathrm{~mol} \%$ $\mathrm{Fe}_{2} \mathrm{O}_{3}$, the Fe-O distance for the first coordination shell is reduced with increasing $\mathrm{SnO}_{2}$ content, while it increases for the second coordination shell. In the samples with $71 \mathrm{~mol} \%$ $\alpha-\mathrm{Fe}_{2} \mathrm{O}_{3}$, the $\mathrm{Fe}-\mathrm{O}$ distance for the first shell increases, but decreases for the second shell. This is related to the changes in the lattice parameters $a$ and $c$ and the oxygen ion position ( $x$ value) in the solid solutions with increasing $\mathrm{SnO}_{2}$ content. It should be noted that an attempt has been made to compare the data listed in Tables IV and V with those obtained by EXAFS measurements for nanostructured $\alpha-\mathrm{Fe}_{2} \mathrm{O}_{3}-\mathrm{SnO}_{2}$ samples prepared by the chemical method. ${ }^{6}$ It was found that for pure $\alpha-\mathrm{Fe}_{2} \mathrm{O}_{3}$, the data given by Kanai et al. ${ }^{6}$ are quite different from the results listed in Tables IV and V, but our results are consistent with the data given by Blake et al. ${ }^{15}$ Nevertheless, the coordination numbers for the $\mathrm{Fe}-\mathrm{Fe}, \mathrm{Sn}-\mathrm{Fe}$, and $\mathrm{Fe}-\mathrm{O}$ bonds were reported to decrease when $\mathrm{Sn}^{4+}$ ions are dissolved in $\alpha-\mathrm{Fe}_{2} \mathrm{O}_{3},{ }^{6}$ in accordance with the results listed in Tables IV and V. According to the interstitial model

TABLE V. Sn-Fe and Fe-O distances $(d)$ and the corresponding average coordination numbers $(\mathrm{CN})$ in the hematite like phase for the 94, 85, and $71 \mathrm{~mol} \% \alpha-\mathrm{Fe}_{2} \mathrm{O}_{3}-\mathrm{SnO}_{2}$ samples with milling times of $110 \mathrm{~h}$ (a) and $151 \mathrm{~h}(\mathrm{~b})$, together with the reference data of pure unprocessed $\alpha-\mathrm{Fe}_{2} \mathrm{O}_{3}$.

\begin{tabular}{|c|c|c|c|c|c|c|c|c|c|c|}
\hline \multirow{2}{*}{$\begin{array}{c}\alpha-\mathrm{Fe}_{2} \mathrm{O}_{3} \\
(\mathrm{~mol} \%)\end{array}$} & \multicolumn{2}{|c|}{$\mathrm{Sn}-\mathrm{Fe}^{\mathrm{a}}$} & \multicolumn{2}{|c|}{$\mathrm{Sn}-\mathrm{Fe}(\mathrm{I})$} & \multicolumn{2}{|c|}{$\mathrm{Sn}-\mathrm{Fe}$ (II) } & \multicolumn{2}{|c|}{$\mathrm{Fe}-\mathrm{O}(\mathrm{I})$} & \multicolumn{2}{|c|}{$\mathrm{Fe}-\mathrm{O}$ (II) } \\
\hline & $d(\AA)$ & $\mathrm{CN}$ & $d(\AA)$ & $\mathrm{CN}^{\mathrm{b}}$ & $d(\AA)$ & $\mathrm{CN}$ & $d(\AA)$ & $\mathrm{CN}^{\mathrm{c}}$ & $d(\AA)$ & $\mathrm{CN}$ \\
\hline 100 & 1.933 & 2.0 & 2.924 & 6.0 & 3.900 & 6.0 & 1.954 & 3.0 & 2.104 & 3.0 \\
\hline 94 & & & 2.926 & 5.9 & 3.885 & 5.9 & 1.917 & 2.9 & 2.172 & 2.9 \\
\hline 85 & & & 2.930 & 5.5 & 3.874 & 5.5 & 1.903 & 2.8 & 2.216 & 2.8 \\
\hline 71 & & & 2.935 & 5.0 & 3.855 & 5.0 & 1.947 & 2.5 & 2.163 & 2.5 \\
\hline 71 & & & 2.934 & 4.7 & 3.848 & 4.7 & 1.962 & 2.2 & 2.141 & 2.2 \\
\hline
\end{tabular}

${ }^{\mathrm{a}} \mathrm{When} \mathrm{Sn}^{4+}$ ions enter into $\alpha-\mathrm{Fe}_{2} \mathrm{O}_{3}$, they occupy the $(0,0,0)$ position. Hence the Sn-Fe distances are those from the $(0,0,0)$ position to the surrounding iron ions.

${ }^{\mathrm{b}} \mathrm{CN}$ is defined as $\mathrm{CN}=\mathrm{CN}_{\text {pure }}\left(g_{\mathrm{Fe}} / g_{\mathrm{Fe}}^{\text {pure }}\right)$ and $g_{\mathrm{Fe}}^{\text {pure }}=1 / 3$.

${ }^{\mathrm{c}} \mathrm{CN}$ is defined as $\mathrm{CN}=\mathrm{CN}_{\text {pure }}\left(g_{\mathrm{O}} / \mathrm{g}_{\mathrm{O}}^{\text {pure }}\right), g_{\mathrm{O}}=0.5-g_{\mathrm{Sn}}$ and $g_{\mathrm{O}}^{\text {pure }}=1 / 2$. 
proposed here, the chemical formula for the $\alpha-\mathrm{Fe}_{2} \mathrm{O}_{3}-\mathrm{SnO}_{2}$ solid solutions should be written as $\mathrm{Sn}_{x} \mathrm{Fe}_{2-2 x} \mathrm{O}_{3-x}$.

\section{CONCLUSIONS}

From the structural refinement analyses of the four asmilled $\alpha-\mathrm{Fe}_{2} \mathrm{O}_{3}-\mathrm{SnO}_{2}$ samples, it can be concluded that $\alpha-\mathrm{Fe}_{2} \mathrm{O}_{3}-\mathrm{SnO}_{2}$ solid solutions with high $\mathrm{SnO}_{2}$ content have been synthesized by mechanical alloying. It was found that the substitution model, as proposed in the literature, cannot be applied to refine the structure of the x-ray diffraction patterns of these solid solutions. An interstitial model, in which the dissolved tin ions occupy empty octahedral holes, has

*Author to whom correspondence should be addressed. Electronic address: jiang@fysik.dtu.dk

${ }^{1}$ M. Takano, Y. Bando, N. Nakanishi, M. Sakai, and H. Okinaka, J. Solid State Chem. 68, 153 (1987).

${ }^{2}$ J. Z. Jiang, S. W. Lu, Y. X. Zhou, S. Mørup, K. Nielsen, F. W. Poulsen, F. J. Berry, and J. McMannus, Mater. Sci. Forum 235238, 941 (1997).

${ }^{3}$ G. H. Moh, Chem. Erde 33, 243 (1974).

${ }^{4}$ J. Cassedane, An. Acade. Bras. Cienc. 38, 265 (1966).

${ }^{5}$ S. Musić, S. Popovic, M. Metikos-Hukovic, and V. Gvozdic, J. Mater. Sci. Lett. 10, 197 (1991).

${ }^{6}$ H. Kanai, H. Mizutani, T. Tanaka, T. Funabiki, S. Yoshida, and M. Tanano, J. Mater. Chem. 2, 703 (1992).

${ }^{7}$ J. Z. Jiang, R. Lin, S. Mørup, K. Nielsen, F. W. Poulsen, F. J. Berry, and R. Clasen, Phys. Rev. B 55, 11 (1997).

${ }^{8}$ F. Schneider, K. Melzer, H. Mehner, and G. Dehe, Phys. Status Solidi A 39, K115 (1977).

${ }^{9}$ P. B. Fabritchnyi, E. V. Lamykin, A. M. Babechkin, and A. N. Nesmeianov, Solid State Commun. 11, 343 (1972).

${ }^{10}$ E. Realo and S. Reiman, in Proceedings of the International Conference on Mössbauer Spectroscopy, Cracow, 1975, edited by A. been suggested. The whole x-ray diffraction patterns for the four samples can be fitted well using the model. It is also found that anionic and cationic vacancies have been formed in these solid solutions. This interstitial model will be further examined in the $\alpha-\mathrm{Fe}_{2} \mathrm{O}_{3}-M \mathrm{O}_{2}(M=$ metal element, e.g., $\mathrm{Ti}$ and $\mathrm{Zr}$ ) systems, which are in progress.

\section{ACKNOWLEDGMENTS}

This work was financially supported by the Danish Research Academy and the Danish Technical Research Council.

Z. Hrynkiewicz and J. A. Sawicki (Wykonano w Powielarni Akademii Gorniczo-Hutniczej im S. Staszica, Cracow, 1975), p. 373.

${ }^{11}$ T. Okada, A. Ambe, F. Ambe, and H. Seklzawa, J. Phys. Chem. 82, 4726 (1982).

${ }^{12}$ J. Z. Jiang, Y. X. Zhou, S. Mørup, and C. B. Koch, Nanostruct. Mater. 7, 401 (1996).

${ }^{13}$ C. J. Howard and R. J. Hill, Program LHMP1, Australian Atomic Energy Commision Report M112, Lucas Hights Research Laboratory, New South Wales, Australia, 1986.

${ }^{14}$ The Rietveld Method, edited by R. A. Young (Oxford University Press, New York, 1993).

${ }^{15}$ R. L. Blake, R. E. Hesserick, T. Zoltai, and L. W. Finger, Am. Mineral. 51, 123 (1966).

${ }^{16}$ A. H. Morrish, Canted Antiferromagnetic: Hematite (World Scientific, Singapore, 1994), p. 19.

${ }^{17}$ J. Z. Jiang et al. (unpublished).

${ }^{18}$ International Tables for X-Ray Crystallography, edited by C. H. Macgillavry, G. D. Rieck, and K. Lonsdale (The Kynoch Press, Birmingham, England, 1968), Vol. 3. 